\title{
Large-scale vertical velocity, diabatic heating and drying profiles associated with seasonal and diurnal variations of convective systems observed in the GoAmazon2014/5 experiment
}

\author{
Shuaiqi Tang ${ }^{1}$, Shaocheng Xie ${ }^{1}$, Yunyan Zhang ${ }^{1}$, Minghua Zhang ${ }^{2}$, Courtney Schumacher ${ }^{3}$, Hannah Upton ${ }^{3}$, \\ Michael P. Jensen ${ }^{4}$, Karen L. Johnson ${ }^{4}$, Meng Wang ${ }^{4}$, Maike Ahlgrimm ${ }^{5}$, Zhe Feng ${ }^{6}$, Patrick Minnis ${ }^{7}$, and \\ Mandana Thieman ${ }^{8}$ \\ ${ }^{1}$ Lawrence Livermore National Laboratory, Livermore, CA 94550, USA \\ ${ }^{2}$ School of Marine and Atmospheric Sciences, Stony Brook University, Stony Brook, NY 11794, USA \\ ${ }^{3}$ Department of Atmospheric Sciences, Texas A\&M University, College Station, TX 77843, USA \\ ${ }^{4}$ Brookhaven National Laboratory, Upton, NY 11973, USA \\ ${ }^{5}$ European Centre for Medium-Range Weather Forecasts, Shinfield Park, Reading RG2 9AX, UK \\ ${ }^{6}$ Pacific Northwest National Laboratory, Richland, WA 99354, USA \\ ${ }^{7}$ NASA Langley Research Center, Hampton, VA 23681, USA \\ ${ }^{8}$ Science Systems and Applications, Inc, Hampton, VA 23666, USA
}

Correspondence to: Shuaiqi Tang (tang32@1lnl.gov)

Received: 19 July 2016 - Published in Atmos. Chem. Phys. Discuss.: 25 July 2016

Revised: 17 October 2016 - Accepted: 28 October 2016 - Published: 16 November 2016

\begin{abstract}
This study describes the characteristics of largescale vertical velocity, apparent heating source $\left(Q_{1}\right)$ and apparent moisture sink $\left(Q_{2}\right)$ profiles associated with seasonal and diurnal variations of convective systems observed during the two intensive operational periods (IOPs) that were conducted from 15 February to 26 March 2014 (wet season) and from 1 September to 10 October 2014 (dry season) near Manaus, Brazil, during the Green Ocean Amazon (GoAmazon2014/5) experiment. The derived large-scale fields have large diurnal variations according to convective activity in the GoAmazon region and the morning profiles show distinct differences between the dry and wet seasons. In the wet season, propagating convective systems originating far from the GoAmazon region are often seen in the early morning, while in the dry season they are rarely observed. Afternoon convective systems due to solar heating are frequently seen in both seasons. Accordingly, in the morning, there is strong upward motion and associated heating and drying throughout the entire troposphere in the wet season, which is limited to lower levels in the dry season. In the afternoon, both seasons exhibit weak heating and strong moistening in the boundary layer related to the vertical convergence of eddy fluxes.
\end{abstract}

A set of case studies of three typical types of convective systems occurring in Amazonia - i.e., locally occurring systems, coastal-occurring systems and basin-occurring systems - is also conducted to investigate the variability of the large-scale environment with different types of convective systems.

\section{Introduction}

Amazonia is one of the major tropical convective regions in the global climate system. It provides moisture to the global hydrological cycle and energy to drive the global atmospheric circulation. Understanding convective systems over the Amazon region through observations is important for understanding and simulating global circulation and climate. However, most of Amazonia is covered by tropical forest with only a few observational sites. In order to collect the observations needed to improve our understanding of convective systems over Amazonia, several major field campaigns have been conducted in this area such as the Amazon Boundary Layer Experiments (Harriss et al., 1988, 1990), the Large-Scale Biosphere-Atmosphere Experiment in Amazo- 
nia (LBA) (Silva Dias et al., 2002b) and the CHUVA project (Machado et al., 2014).

Recently, an internationally collaborative experiment, the Observations and Modeling of the Green Ocean Amazon (GoAmazon2014/5) (Martin et al., 2016), was conducted in the region around Manaus, Brazil, from January 2014 to December 2015 with a focus on the aerosol and cloud life cycles and aerosol-cloud-precipitation interactions over tropical rainforests. Two 40-day intensive operational periods (IOPs) were conducted in 2014 to investigate the seasonal variations of clouds and aerosols, as well as their interactions. IOP1 took place from 15 February to 26 March 2014 during the wet season, and IOP2 took place from 1 September to 10 October 2014 during the dry season. The goal of this study is to document and understand the seasonal variability and diurnal cycle of large-scale vertical velocity, heat and moisture budgets associated with the convective systems observed during the two IOPs in the GoAmazon2014/5 experiment.

The Amazon region has a significant seasonal variation in precipitation amount. Rainfall is approximately $300 \mathrm{~mm}$ per month during the wet season, while it is close to $100 \mathrm{~mm}$ per month during the dry season (Tanaka et al., 2014). Many studies have examined the seasonal variation of clouds and precipitation in Amazonia (e.g., Harriss et al., 1988, 1990; Fu et al., 1999, 2001; Schumacher and Houze, 2003; Machado et al., 2004; Li et al., 2006; Nobre et al., 2009; Marengo et al., 2012; Filho et al., 2015). Compared to the large variation in clouds and rainfall, the seasonal variation in CAPE is small (Machado et al., 2004; Martin et al., 2016). Martin et al. (2016) suggest that small perturbations in the large-scale circulation can drive dramatic changes in hydrological fields in this region. Few, however, have studied the seasonal variation of the diabatic heating and drying structures associated with the convective systems in the Amazon region.

The diurnal cycle of the atmosphere is an important feature that is poorly simulated in climate models. Many efforts have been made to observe and to understand the diurnal cycle over the Amazon basin using surface observations (e.g., Harriss et al., 1990; Cutrim et al., 2000; Machado et al., 2004; Tanaka et al., 2014) or satellite data (e.g., Minnis and Harrison, 1984; Greco et al., 1990; Janowiak et al., 2005; Burleyson et al., 2016). The diurnal cycle over the Amazon basin is complex because it is affected by three types of convective systems (Greco et al., 1990): locally occurring systems (LOS) generated locally in the form of small convective cells (area less than $1000 \mathrm{~km}^{2}$ ) with short lifetime (on the order of $1 \mathrm{~h}$ ), coastal-occurring systems (COS) initialized at the northeast coast of Brazil by the sea breeze and propagating inland as squall lines and basin-occurring systems (BOS) initialized in the Amazon basin in the form of mesoscale convective systems (MCSs) with areas larger than $1000 \mathrm{~km}^{2}$. These systems reach Manaus, near the center of the Amazon basin, at different times of the day, causing a broad peak of precipitation from morning to early afternoon (e.g., Machado et al., 2004; Tanaka et al., 2014; Burleyson et al., 2016). Schumacher et al. (2007) examined the diurnal cycle of the large-scale heating budget in the southwest Amazon during LBA but used only two profiles per day, which do not capture the rapidly changing environment. In addition, the diurnal cycle over the highly deforested southwest Amazon is not necessarily representative of the more pristine central Amazonian rainforest.

In this study we use data collected from the comprehensive GoAmazon2014/5 field campaign to examine the seasonal and diurnal variations of the large-scale vertical velocity and heat and moisture budgets associated with the convective systems that occur in central Amazonia. Section 2 provides details of the data and method used to derive the large-scale profiles for the GoAmazon2014/5 experiment. Section 3 describes the synoptic conditions for the two IOPs. Sections 4 and 5 show the seasonal variation and diurnal cycle of the large-scale fields, respectively. Section 6 further investigates three selected cases representing different types of convective systems in the wet season. The summary and discussion are given in Sect. 7. Data availability is provided in Sect. 8.

\section{Data and methods}

Due to the lack of an appropriate sounding array to capture the divergence and advection fields in the analysis domain, the large-scale vertical velocity and budgets analyzed in this study were derived by using, as a first guess, the $0.5^{\circ} \times 0.5^{\circ}$ European Centre for Medium-Range Weather Forecasts (ECMWF) analysis data that are subsequently constrained with domain-averaged surface and top of atmosphere (TOA) observations. The upper-level fields from ECMWF analysis data are adjusted to conserve the vertical integration of mass, moisture and dry static energy through a constrained variational analysis technique described in Zhang and Lin (1997) and Zhang et al. (2001). As indicated in Xie et al. (2004), the use of the surface and TOA observations as constraints improves the quality of the large-scale vertical velocity and budgets in operational analysis data and makes the data suitable for budget analysis and cloud modeling studies. An important byproduct of this study is the derived large-scale forcing data (ARM Climate Research Facility, 2001) supporting modeling studies, which are available to the community at the Atmospheric Radiation Measurement (ARM) program archive (http://iop.archive.arm.gov/ arm-iop/0eval-data/xie/scm-forcing/iop_at_mao/).

Figure 1 shows the location of the GoAmazon2014/5 experiment and the analysis domain (the red octagon, referred to as the GoAmazon domain) used in this study, which is about $110 \mathrm{~km}$ in radius. The observational research sites and major cities near the region are also shown on the map. The required surface and TOA fluxes as the constraints for the variational analysis are constructed as follows. The precipitation used in this study is derived from the System for 

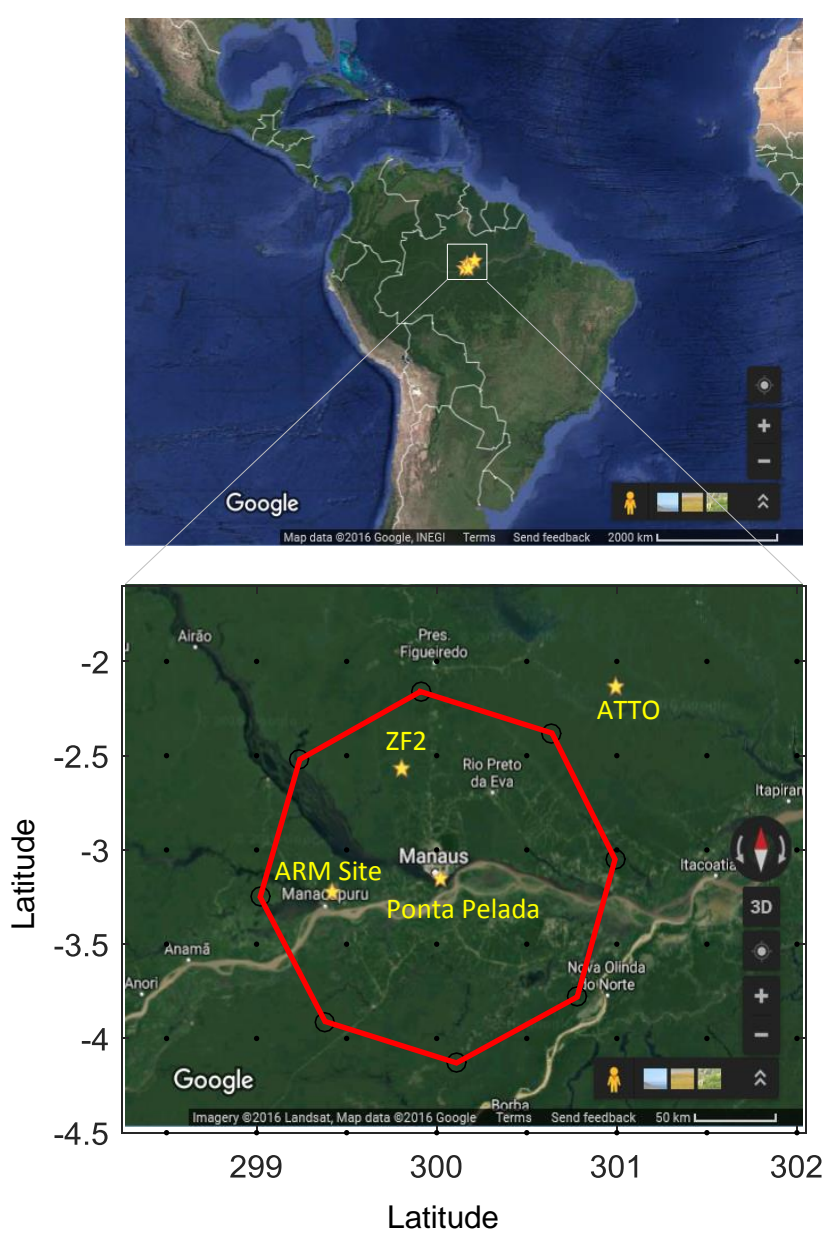

Figure 1. The location of GoAmazon site in this study. The red octagon represents the analysis domain. Locations of observational sites are indicated by yellow pentagrams. Locations of cities are indicated by white dots.

the Protection of Amazonia (SIPAM) S-band $(10 \mathrm{~cm}$ wavelength) radar operated at Ponta Pelada airport, the center of the GoAmazon domain. The SIPAM radar reflectivity constant altitude plan position indicator (CAPPI) at $2.5 \mathrm{~km}$ above ground was used to generate the rain rate products using a single $Z-R$ relation of $Z=174.8 R^{1.56}$ derived from JossWaldvogel disdrometer data obtained by the CHUVA campaign near Manacapuru during the wet season of early 2014. Other surface constraint variables, such as surface radiative fluxes and latent and sensible heat fluxes, are obtained from the broadband radiometer (ARM Climate Research Facility, 1994) and eddy correlation flux measurement system (ARM Climate Research Facility, 2003) at the ARM Mobile Facility site near Manacapuru $\left(3.213^{\circ} \mathrm{S}, 60.598^{\circ} \mathrm{W}\right.$; "ARM site" in Fig. 1). Observations of latent and sensible heat fluxes at two other Brazilian research sites - K34 ("ZF2" in Fig. 1) and the Amazon Tall Tower Observatory ("ATTO" in Fig. 1) - are also used. The TOA measurements of broadband radia- tive fluxes are estimated from the 13th Geostationary Operational Environmental Satellite (GOES-13) $4 \mathrm{~km}$ visible $(0.65 \mu \mathrm{m})$ and infrared window $(10.8 \mu \mathrm{m})$ radiances using the narrowband-to-broadband conversion method of Minnis and Smith (1998) that was updated similarly to Khaiyer et al. (2010), with some modifications to more closely match those measured by the Clouds and Earth's Radiant Energy System (CERES) on the Aqua and Terra satellites. The radar precipitation and satellite data are 3-hourly average over the analysis domain. The surface radiative fluxes and latent and sensible heat fluxes are first averaged into $3 \mathrm{~h}$ resolution. Then we use the Cressman's objective analysis method (Cressman, 1959) to incorporate these limited number of observations with the ECMWF gridded analysis and calculate the domain mean, so that the domain-mean surface fluxes can better represent the entire domain. The derived large-scale vertical velocity and budgets are thus representing a $3 \mathrm{~h}$ average over analysis domain. The vertical resolution is $25 \mathrm{hPa}$.

\section{Background of synoptic conditions}

The IOP-averaged sea-level pressure and $10 \mathrm{~m}$ horizontal winds from ERA-Interim reanalysis (Dee et al., 2011) are plotted in Fig. 2. During IOP1, the Atlantic Intertropical Convergence Zone (ITCZ) was located near the Equator; during IOP2, it was located near $10^{\circ} \mathrm{N}$. A fourteen-day trajectory study shows that the air masses over Manaus typically come from the Northern Hemisphere during IOP1 and from the Southern Hemisphere during IOP2 (Martin et al., 2016). The top three rows of Fig. 3 show the domain-averaged zonal $(u)$ wind, meridional $(v)$ wind and relative humidity relative to liquid water, from the adjusted ECMWF analysis. Consistent with those derived from radiosonde data in Martin et al. (2016), IOP1 was dominated by northeasterly winds in the lower troposphere, with moist air throughout the troposphere; IOP 2 was dominated by easterly winds in the lower troposphere, with a dry free troposphere.

The cloud frequency and domain-mean precipitation observed during IOP1 and IOP2 are shown in the remaining two rows of Fig. 3. The cloud frequency was derived from the Active Remote Sensing of Clouds (ARSCL) (Kollias et al., 2007) product, which uses a combination of the $95 \mathrm{GHz}$ W-band ARM cloud radar (WACR), micropulse lidar (MPL) and ceilometer located at the ARM site pointing upward to determine a best-estimate cloud mask above the ARM site with $5 \mathrm{~s}$ temporal and $30 \mathrm{~m}$ vertical resolution. The ARSCL product leverages each instrument's strengths: the WACR penetrates non-precipitating and weakly precipitating thick clouds, the MPL is sensitive to thin clouds and the ceilometer reliably detects cloud base. The ARSCL-derived cloud mask data were then used to produce 3-hourly cloud frequencies following the method described in Xie et al. (2010b). The wet season has more cloud and precipitation events than the dry season. However, the convective systems in the dry sea- 

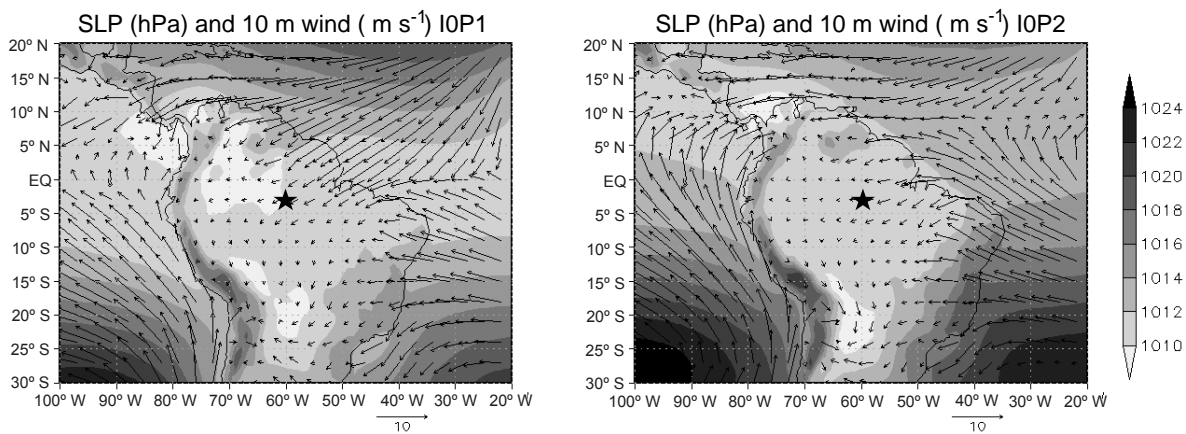

Figure 2. The sea-level pressure (shaded) and $10 \mathrm{~m}$ horizontal wind (vector) averaged for IOP1 (left) and IOP2 (right). The pentagram indicates the location of GoAmazon site.
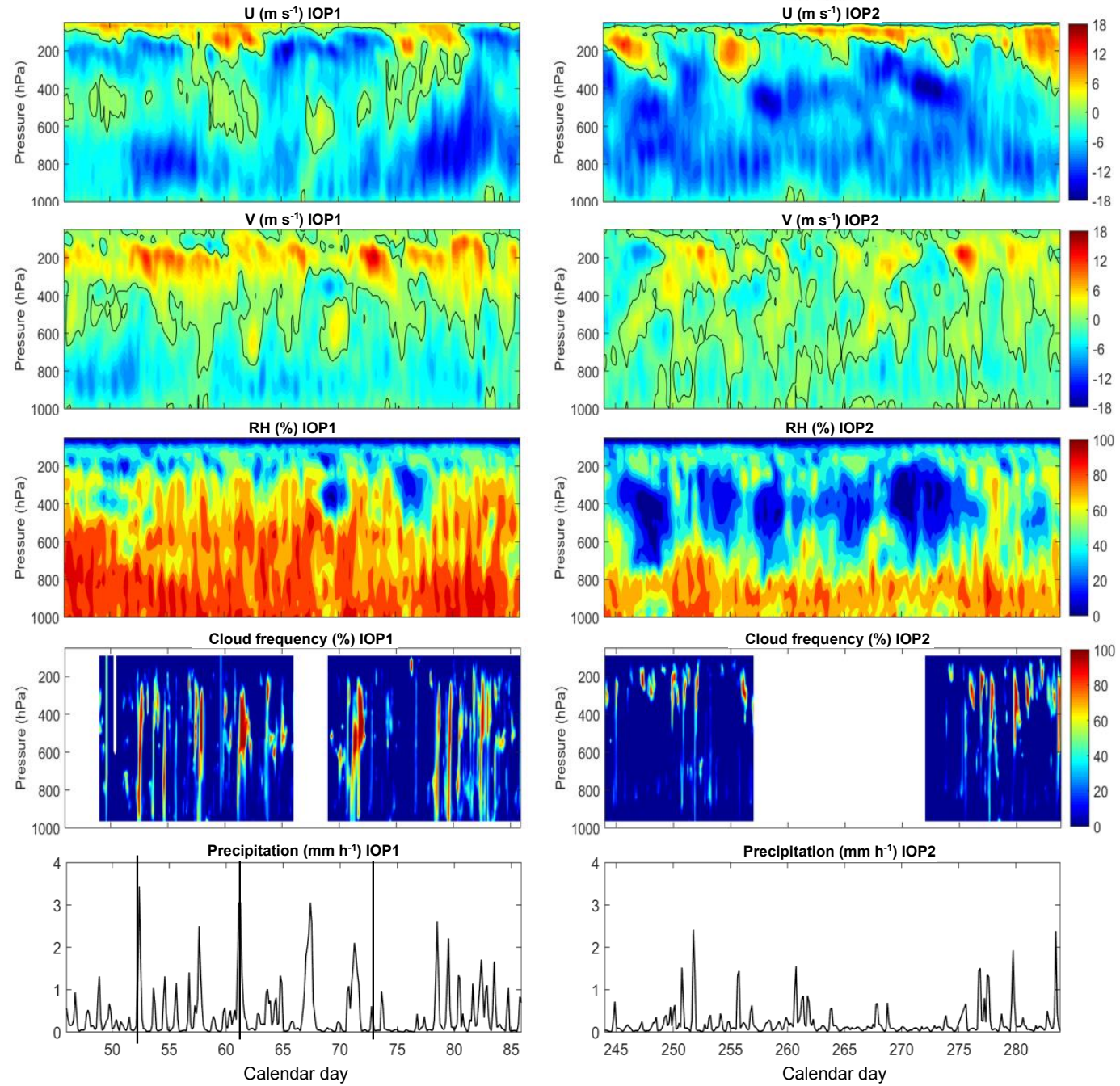

Figure 3. Domain-averaged time series of (from top to bottom) horizontal $(u)$ wind, meridional $(v)$ wind, relative humidity, cloud frequency (point observation at the ARM site) and precipitation for IOP1 (left) and IOP2 (right). The blank areas in cloud frequency indicate missing data. The three straight black lines in IOP1 show the three cases chosen in Sect. 6 . 

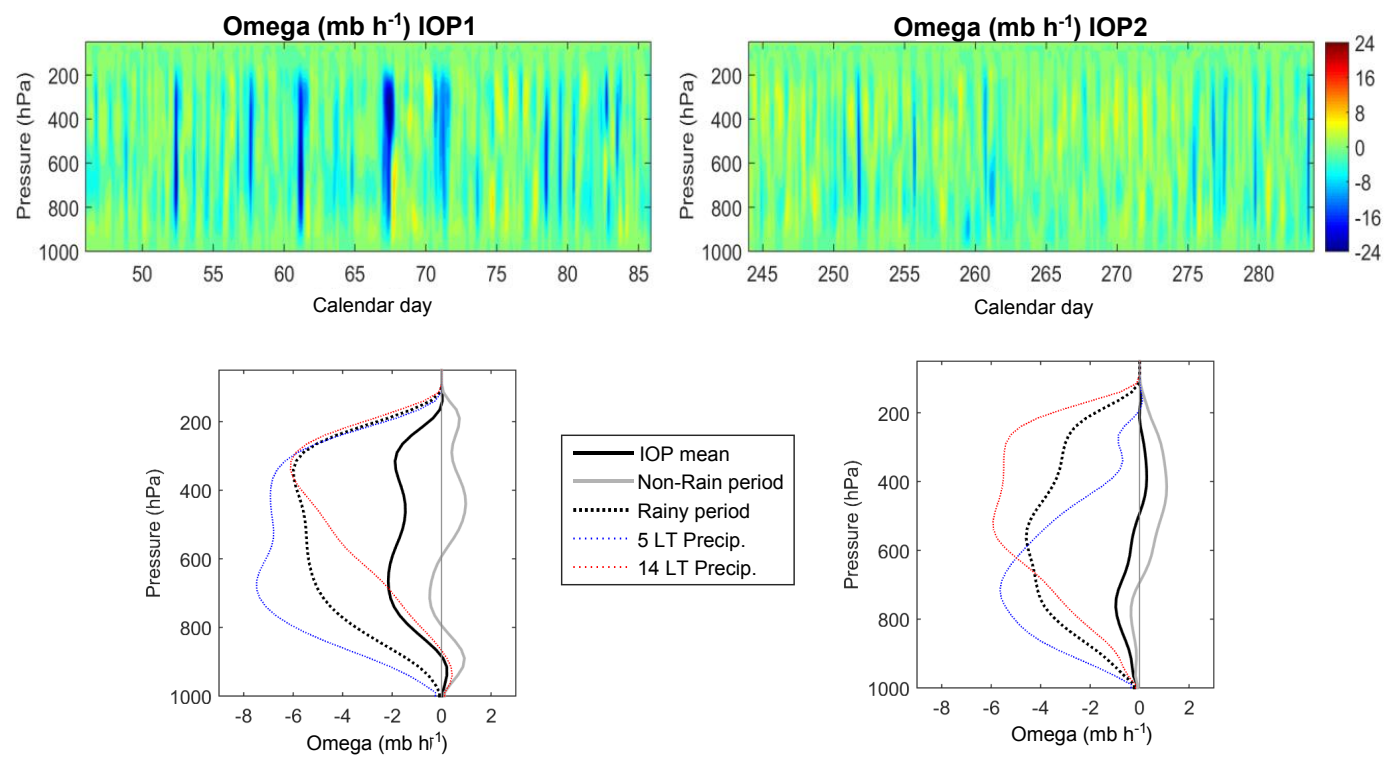

Figure 4. The time series (top) and temporal mean profiles (bottom) of large-scale vertical velocity for IOP1 (left) and IOP2 (right).

son are typically more intense than those occurring in the wet season (Giangrande et al., 2016). Compared to 15-year climatology, the precipitation around Manaus during 2014 has a positive anomaly in IOP1 and negative anomaly in IOP2 (Burleyson et al., 2016; Martin et al., 2016). Nevertheless, the annual cycle in 2014 is still broadly representative of the climatology (Burleyson et al., 2016).

\section{Seasonal variation}

In this section, we focus on the contrast between the dry and wet season large-scale vertical velocity and energy and moisture budgets. The upper row of Fig. 4 shows the temporal evolution of large-scale vertical velocity in IOP1 (wet season, left) and IOP2 (dry season, right), and the IOP-mean profiles are shown as the black solid lines in the bottom row. We also define rainy (black dotted lines) and non-rain periods (gray lines) using a threshold of $0.2 \mathrm{~mm} \mathrm{~h}^{-1}$. A value of $0.2 \mathrm{~mm} \mathrm{~h}^{-1}$ rather than $0 \mathrm{~mm} \mathrm{~h}^{-1}$ is used because in some cases ground clutter in the SIPAM radar data may be misinterpreted as light precipitation. Changing the threshold affects the magnitude of the vertical profiles but does not change the seasonal contrast and the results of this study. Using this threshold, the percentage of the rainy period to the entire IOP is $36.9 \%$ for IOP1 but is $17.8 \%$ for IOP2, indicating that the rain frequency is an important factor impacting the seasonal mean contrast. The red and blue lines represent the mean profiles of morning (at 05:00 local time (LT)) precipitation systems and afternoon (at 14:00 LT) precipitation systems, respectively, which will be discussed in Sect. 5.

The non-rain vertical velocity profiles are relatively weak, with downward motion dominating in the upper troposphere during both dry and wet seasons. The rainy vertical velocity profiles show strong upward motion throughout the troposphere during both IOPs, but the level of maximum upward motion is different. The upward motion during the rainy period of IOP1 has a broad peak structure from $\sim 700$ to $300 \mathrm{hPa}$ with the maximum at $\sim 350 \mathrm{hPa}$. The $350 \mathrm{hPa}$ upward motion peak is consistent with that shown in the Tropical Ocean and Global Atmosphere Coupled OceanAtmosphere Response Experiment (TOGA COARE) (Lin and Johnson, 1996), but lower than the peak of $\sim 265 \mathrm{hPa}$ observed in the Tropical Warm Pool-International Cloud Experiment (TWP-ICE) (Xie et al., 2010a). The upward motion during the IOP2 rainy period also has a broad peak but the maximum is at a much lower level $(\sim 550 \mathrm{hPa})$ than in IOP1. Because the frequency of the rainy period is higher in IOP1 than in IOP2, the IOP-mean upward motion is stronger during IOP1 but weaker and limited to the lower troposphere during IOP2. As discussed in the next section, the difference in morning precipitation systems largely contributes to the seasonal contrast in the vertical velocity profiles between the wet and dry seasons.

Figures 5 and 6 show the temporal evolution and IOPmean of apparent heating $Q_{1}$ and apparent drying $Q_{2}$ profiles, respectively. $Q_{1}$ and $Q_{2}$ were first introduced by Yanai et al. (1973) to estimate the diabatic processes:

$$
\begin{aligned}
& Q_{1}=\frac{1}{c_{p}}\left(\frac{\partial \bar{s}}{\partial t}+\overline{\boldsymbol{V}} \cdot \nabla \bar{s}+\bar{\omega} \frac{\partial \bar{s}}{\partial p}\right) \\
& =\frac{1}{c_{p}}\left(Q_{\mathrm{rad}}+L_{v}(c-e)-\frac{\partial \overline{\omega^{\prime} s^{\prime}}}{\partial p}\right)
\end{aligned}
$$



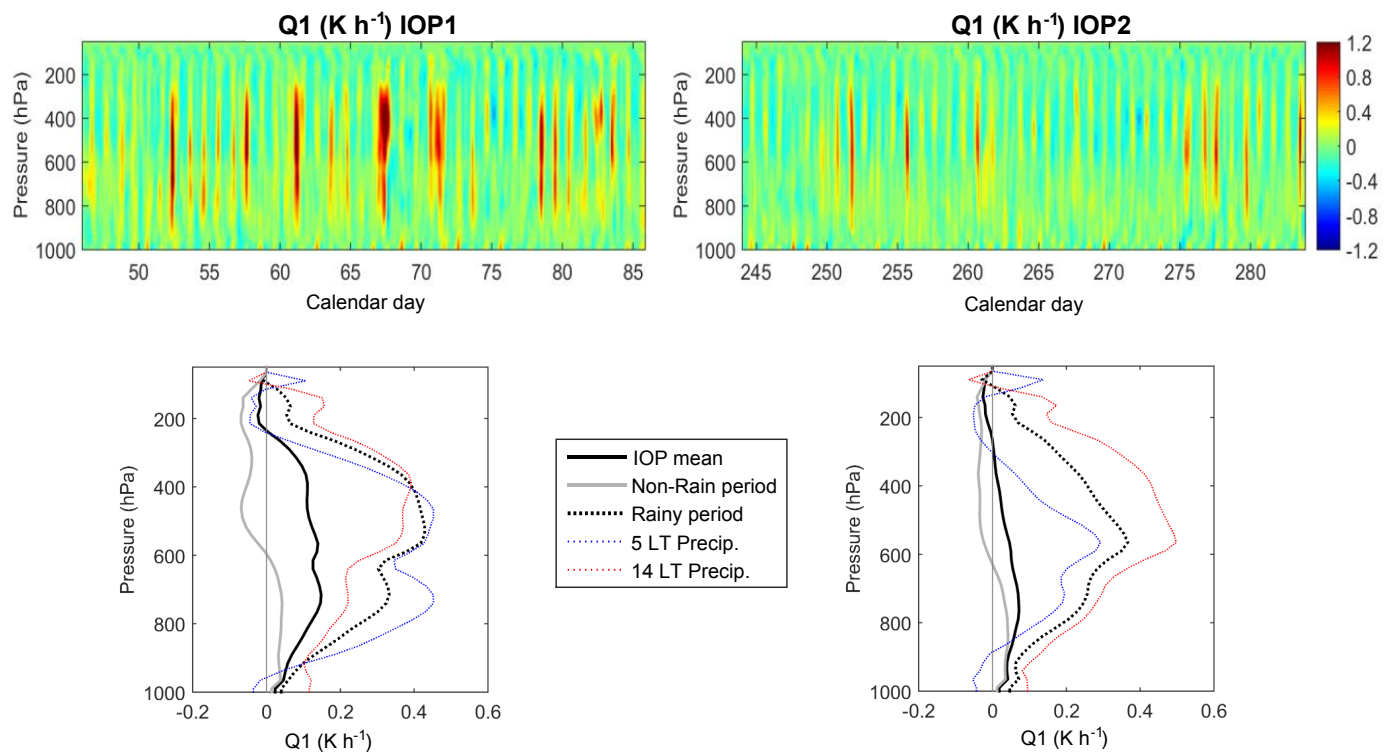

Figure 5. The time series (top) and temporal mean profiles (bottom) of apparent heating source $Q_{1}$ for IOP1 (left) and IOP2 (right).
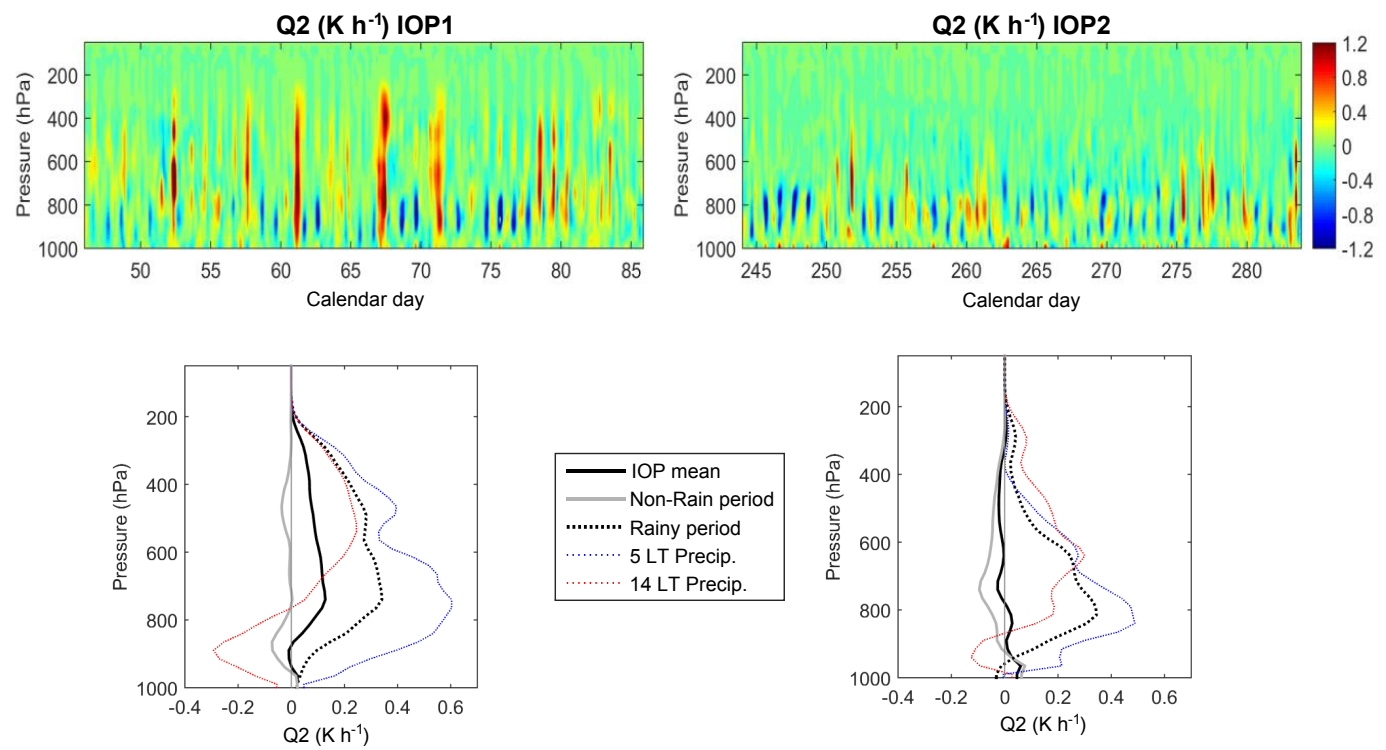

Figure 6. The time series (top) and temporal mean profiles (bottom) of apparent moisture sink $Q_{2}$ for IOP1 (left) and IOP2 (right).

$$
\begin{aligned}
& Q_{2}=-\frac{L_{v}}{c_{p}}\left(\frac{\partial \bar{q}}{\partial t}+\overline{\boldsymbol{V}} \cdot \nabla \bar{q}+\bar{\omega} \frac{\partial \bar{q}}{\partial p}\right) \\
& =\frac{L_{v}}{c_{p}}\left(c-e+\frac{\partial \overline{\omega^{\prime} q^{\prime}}}{\partial p}\right),
\end{aligned}
$$

where $s=c_{p} T+g z$ is the dry static energy and $c_{p}$ is the specific heat for dry air in constant pressure, $q$ is water vapor mixing ratio, $\boldsymbol{V}$ is horizontal wind vector, $\omega$ is vertical velocity in pressure coordinate, $Q_{\text {rad }}$ is radiative heating and $L_{v}(c-e)$ is the latent heat from water condensation and evaporation (in general it also includes the latent heat and water vapor change from ice phase change). The overbar refers to a horizontal average and the prime refers to a deviation from the average. $Q_{1}$ and $Q_{2}$ are calculated from the largescale dynamics (the first lines of the equations) and represent the unresolved physical heat sources and moisture sinks (the second lines). Because the thermodynamic equation and water vapor conservation equation are explicitly satisfied in the variational analysis and the observed precipitation is used as the constraint, the vertical integral of $Q_{1}-Q_{\text {rad }}$ and vertical integral of $Q_{2}$ are consistent with the observed precipitation rate implicitly. The vertical distributions of heating and 
drying profiles are important to the large-scale circulation as discussed in many other studies (e.g., Hartmann et al., 1984; Lau and Peng, 1987; Puri, 1987; Hack and Schubert, 1990).

Overall, the magnitude of $Q_{1}$ and $Q_{2}$ are consistent with Schumacher et al. (2007) for LBA at southwestern Brazilian Amazon but much smaller than Greco et al. (1994) at Manaus region. The much larger magnitude in Greco et al. (1994) is likely because it is a case study of 1 day. The peak height in this study is also lower than the other two studies, indicating that our cases contain more shallow cumulus and convections with low-level heating and drying.

Similar to the profiles of vertical velocity, non-rain $Q_{1}$ and $Q_{2}$ profile magnitudes in both IOPs are weak with small amounts of heating and moistening below $600 \mathrm{hPa}$ indicative of non-precipitating or very weakly precipitating shallow cumulus and congestus clouds (Schumacher et al., 2008). Rainy period $Q_{1}$ and $Q_{2}$ profiles show strong heating and drying throughout the troposphere during both IOPs associated with deep convection, and both of them have double peak structures that vary between dry and wet seasons. $Q_{1}$ during IOP1 has a broad primary peak between 600 and $400 \mathrm{hPa}$, while the primary $Q_{1}$ peak during IOP2 maximizes more sharply at $550 \mathrm{hPa}$. The secondary peaks of $Q_{1}$ are at $\sim 750 \mathrm{hPa}$ in both IOPs. The peaks of $Q_{2}$ in IOP1 (at 500 and $750 \mathrm{hPa}$ ) are higher than those in IOP2 (at 650 and $800 \mathrm{hPa}$ ). The double peak features of $Q_{1}$ and $Q_{2}$ are likely due to different physical processes. For $Q_{1}$, previous studies (Johnson, 1984; Schumacher et al., 2007) interpreted the double peaks as a result from shallow cumulus in lower level and deep convection or MCS in middle to upper level, although sometimes they superposed as one peak (Johnson, 1984). Moreover, latent cooling due to ice melting in the stratiform region may also contribute to the local minimum of $Q_{1}$, which, in some field campaigns, is only shown as an inflection (Johnson et al., 2016). Nevertheless, the local minimum or the inflection usually occurs near the melting level $(\sim 600 \mathrm{hPa})$ in many other tropical field campaigns (e.g., Schumacher et al., 2008; Xie et al., 2010a; Ahmed et al., 2016), indicating that the melting level is nearly constant in the tropics. For $Q_{2}$, the double-peak structure is the combined effect of convective (lower peak) and stratiform (higher peak) rain production (Lin and Johnson, 1996). The peak levels for stratiform and convective clouds may vary in different locations and times such as in the two IOPs in this study.

\section{Diurnal cycle}

The diurnal cycles of domain-mean radar-derived precipitation and surface CAPE and convective inhibition (CIN) for both IOPs are plotted in Fig. 7. Precipitation in IOP1 extends from early morning to afternoon, consistent with Tanaka et al. (2014). In IOP2, most of the precipitation occurs in the afternoon. The magnitude of afternoon precipitation in IOP2 is just slightly smaller than that in IOP1, but the magnitude of
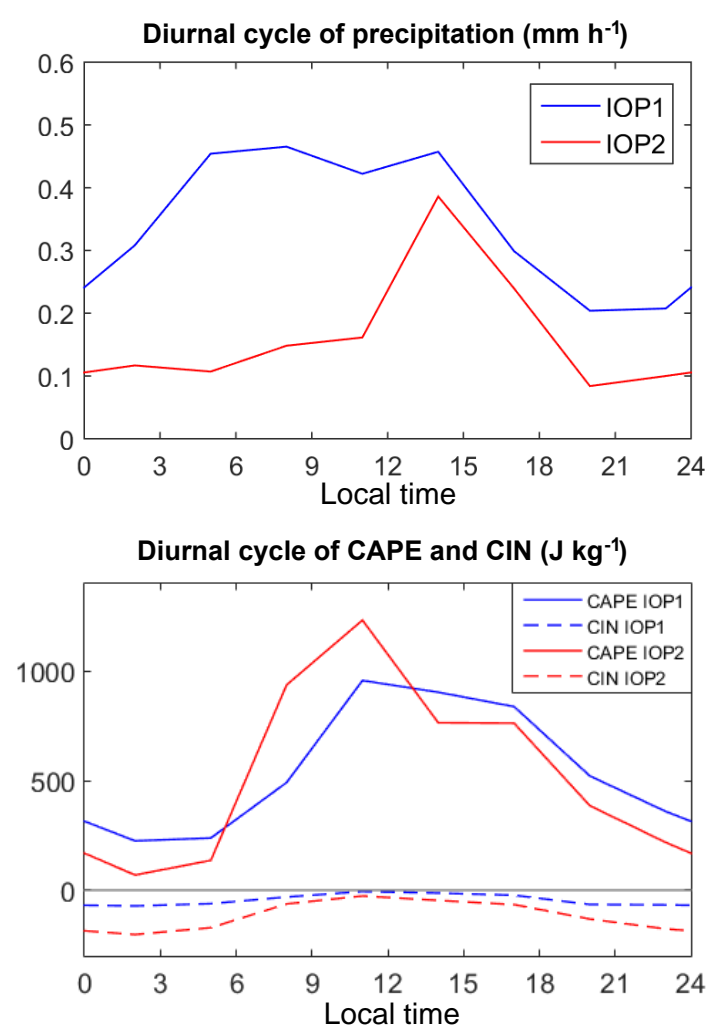

Figure 7. The diurnal cycle of precipitation (up) and CAPE and CIN (bottom) for both IOPs.

morning precipitation in IOP2 is significantly lower than that in IOP1, indicating that the differences between dry and wet seasons are mainly due to the morning precipitation events. The surface CAPE has similar magnitudes in the daytime during IOP1 and IOP2, but in the early morning it rises later and slower during IOP1 than during IOP2, probably because early morning precipitation during IOP1 has released atmospheric instability. The surface CIN is typically small, especially during IOP1, which is due to the high surface relative humidity over the Amazon rainforest.

The diurnal cycles of cloud frequency, large-scale vertical velocity, $Q_{1}, Q_{2}$ and $Q_{1}-Q_{2}-Q_{\text {rad }}$ for IOP1 (left) and IOP2 (right) are shown in Fig. 8. Derived from Eqs. (1) and (2),

$Q_{1}-Q_{2}-Q_{\mathrm{rad}}=-\frac{1}{c_{p}} \frac{\partial \overline{\omega^{\prime} h^{\prime}}}{\partial p}$,

where $h=s+L_{v} q$ is the moist static energy, and $Q_{\text {rad }}$ is estimated from using the radiative transfer model in the singlecolumn model of CAM5 (Neale et al., 2012) driven by the large-scale forcing data derived from this study since it cannot be directly measured and $Q_{\text {rad }}$ retrievals from observed vertical cloud profiles (Feng et al., 2014) have not been available yet. With the freezing and melting processes ignored, $Q_{1}-Q_{2}-Q_{\text {rad }}$ represents the vertical convergence of $h$ by sub-grid turbulence and cumulus. 

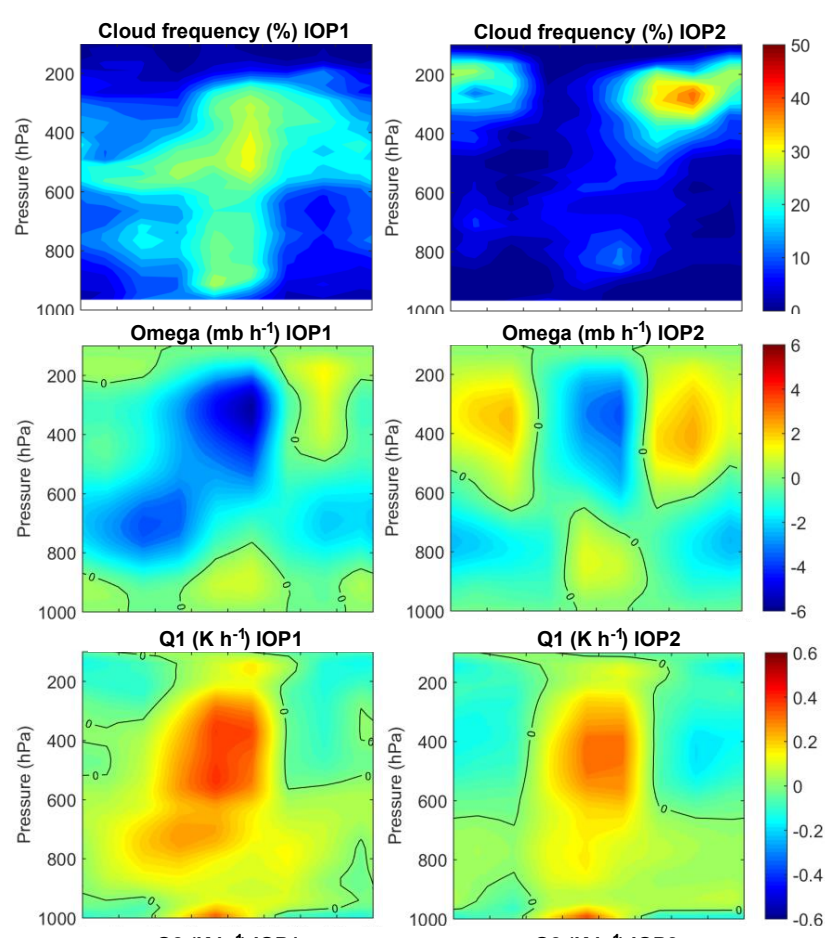

Q2 $\left(K^{-1}\right)$ IOP1
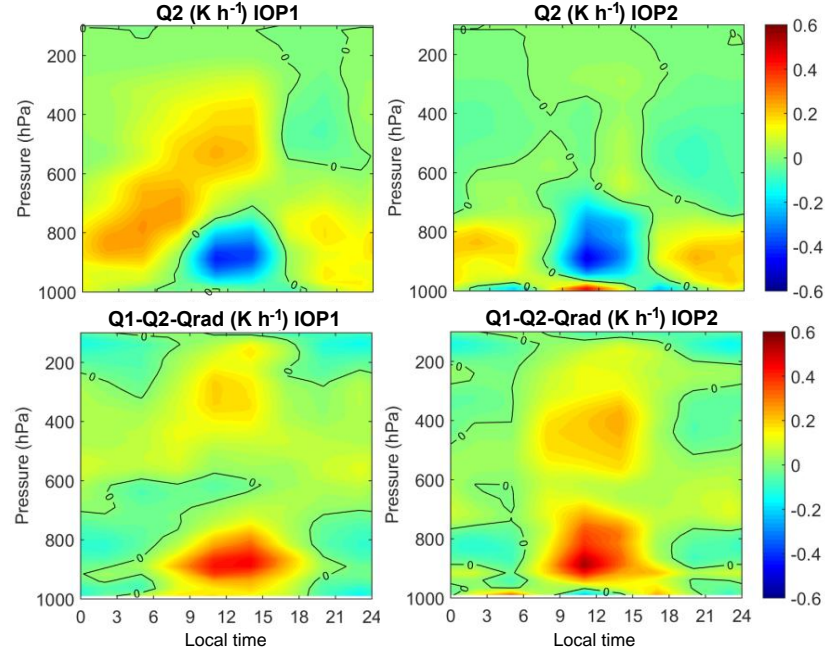

Figure 8. The diurnal cycle of (from top to bottom) cloud frequency, large-scale vertical velocity, $Q_{1}, Q_{2}$ and $Q_{1}-Q_{2}-Q_{\text {rad }}$ for IOP1 and IOP2. The black lines are zero-lines.

Consistent with the diurnal cycles of precipitation, the observed clouds and large-scale vertical velocity differ primarily in the morning between IOP1 and IOP2. In IOP1, the early morning upward motion peaks at $700 \mathrm{hPa}$ and extends to the upper troposphere around $200 \mathrm{hPa}$. The early afternoon upward motion peaks at the upper troposphere and extends above $100 \mathrm{hPa}$. Accordingly, clouds are mainly seen between 800 and $500 \mathrm{hPa}$ in the early morning but throughout the entire troposphere in the afternoon. In IOP2, morning convective systems are generally limited to the lower levels, as shown by weak upward motion below $600 \mathrm{hPa}$ and downward motion above. Thus, few clouds are observed in the lower and middle troposphere while some high clouds remain from the previous day's convective activities. The afternoon convective systems are strong and deep in both IOPs, with upward motion in the upper troposphere associated with convective cloud growth and downward motion in the lower troposphere associated with convective downdrafts.

Consistent with the clouds and vertical velocity, Fig. 8 also shows significant seasonal differences of $Q_{1}$ and $Q_{2}$ profiles in the morning, with heating and drying extending to the upper troposphere in IOP1 but cooling and moistening above $600-650 \mathrm{hPa}$ in IOP2. In the afternoon, both IOPs show strong heating and drying in the middle and upper troposphere with weak heating and strong moistening occurring below $700 \mathrm{hPa}$. The low-level heating and moistening feature has been observed in trade wind regimes during westerly wind bursts and monsoon break periods (Nitta and Esbensen, 1974; Lin and Johnson, 1996; Johnson and Lin, 1997; Xie et al., 2010a), in which the vertical convergence of eddy fluxes and detrainment of shallow cumulus were considered as the causes. In this study it is also seen in the afternoon precipitating periods (red lines in Figs. 5 and 6). To further investigate this feature, $Q_{1}-Q_{2}-Q_{\text {rad }}$ is shown in the last row of Fig. 8. Two positive $Q_{1}-Q_{2}-Q_{\text {rad }}$ centers are seen during daytime between 750 and $950 \mathrm{hPa}$ and between 250 and $550 \mathrm{hPa}$, respectively. It is likely that the positive $Q_{1}-Q_{2}-Q_{\text {rad }}$ in the lower level (below $600 \mathrm{hPa}$ ) is mainly due to the vertical convergence of $h$ by boundary layer turbulence and shallow cumulus. The positive $Q_{1}-Q_{2}-Q_{\text {rad }}$ in the upper troposphere (above $600 \mathrm{hPa}$ ) is likely due to the vertical convergence of $h$ by deep convective process. Note that $Q_{1}-Q_{2}-Q_{\text {rad }}$ also includes latent heat from ice freezing and melting, which may contribute to the local minimum around $600 \mathrm{hPa}$.

\section{Case studies}

A set of case studies is conducted to further understand the large-scale vertical velocity and heat and moisture budgets for the three typical types of convective systems (Greco et al., 1990) that often occur in the wet season in Amazonia: LOS, COS and BOS. Previous studies have found that LOS often occur in the afternoon characterized as scattered convections generated through solar heating at the surface, while most COS and BOS are propagating systems associated with midlevel easterlies and westerlies, respectively (e.g., Cifelli et al., 2002; Silva Dias et al., 2002a; Williams et al., 2002), and affect Manaus in the early morning. COS occurring in easterlies are often westwardpropagating squall lines with intense leading lines that are more vertically developed. BOS generated in the westerlies are generally less vertically developed MCSs with a broad horizontal area and relatively homogeneous precipitation extending over a long time (Cifelli et al., 2002). Table 1 gives the number of each type of precipitation sys- 

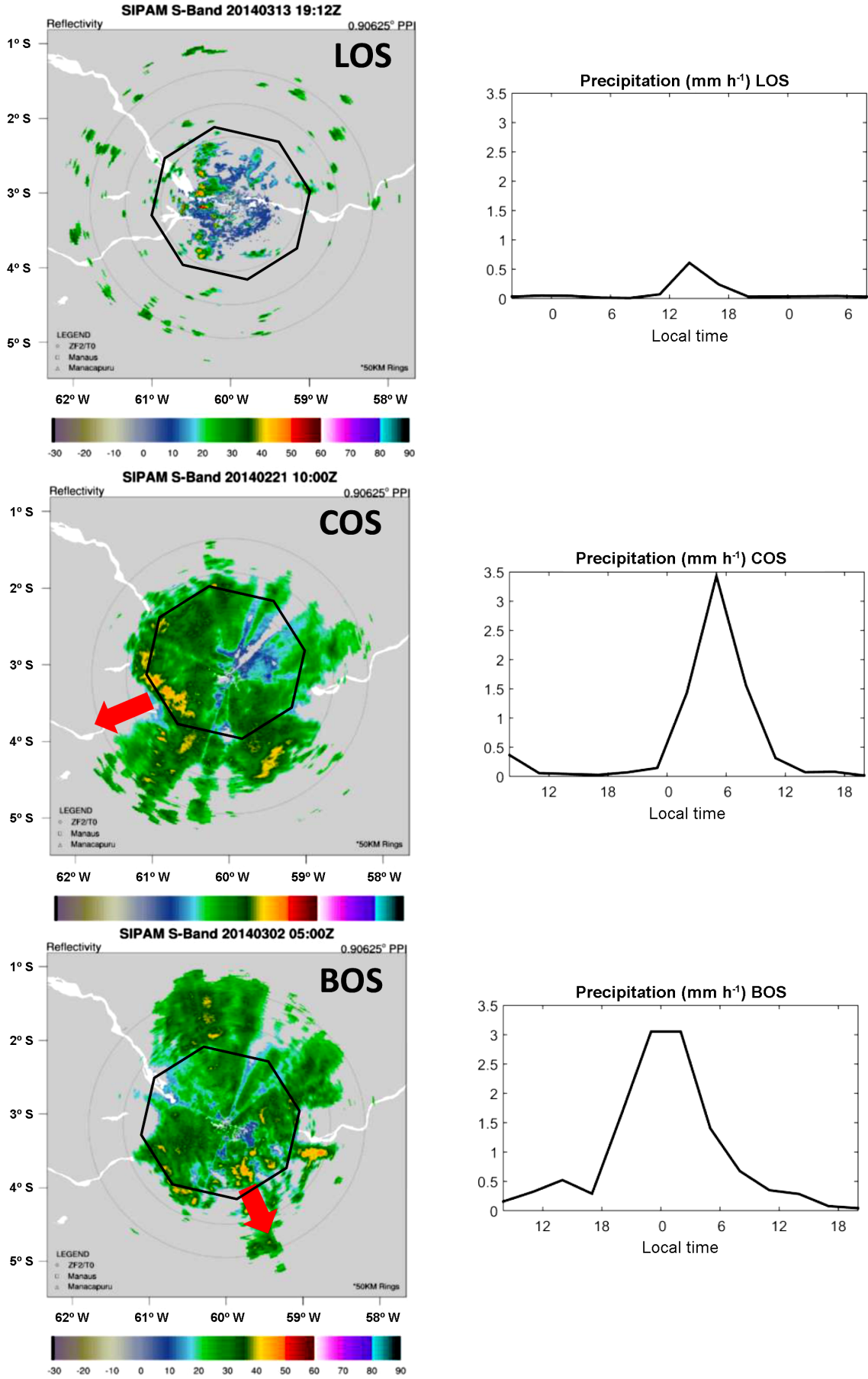

Figure 9. SIPAM radar reflectivity snapshots (left) and time series of domain-mean precipitation (right) for three cases of precipitating systems. From top to bottom: LOS, COS and BOS. The black octagons indicate the GoAmazon domain, and the red arrows indicate the propagating direction of the system.

tem observed during the two IOPs, identified from the radar loop (available at https://www.youtube.com/playlist?list= PLVqbwaasmlvtcu2kl_U5RaaNF0kYqW6ua) and the satellite infrared images (available at http://www-pm.larc.nasa. gov/). There are some cases in the easterlies identified as
BOS because they initiated in the Amazon basin but their structures are more like COS as squall lines. More COS and BOS are seen in IOP1 than in IOP2, but the number of afternoon LOS in IOP1 is just slightly higher than that in IOP2. This again indicates that the frequency of morning propa- 
Table 1. Number of convective systems identified in the morning and afternoon during IOP1 and IOP2.

\begin{tabular}{lrr|rr}
\hline & \multicolumn{2}{c|}{ IOP1 } & \multicolumn{2}{c}{ IOP2 } \\
\cline { 2 - 5 } & Morning & Afternoon & Morning & Afternoon \\
\hline Locally occurring systems (LOS) & 0 & 19 & 0 & 16 \\
Coastal occurring systems (COS) & 8 & 2 & 0 & 1 \\
Basin occurring systems (BOS) & 8 & 1 & 3 & 2 \\
\hline
\end{tabular}

\section{LOS (14 March 2014)}
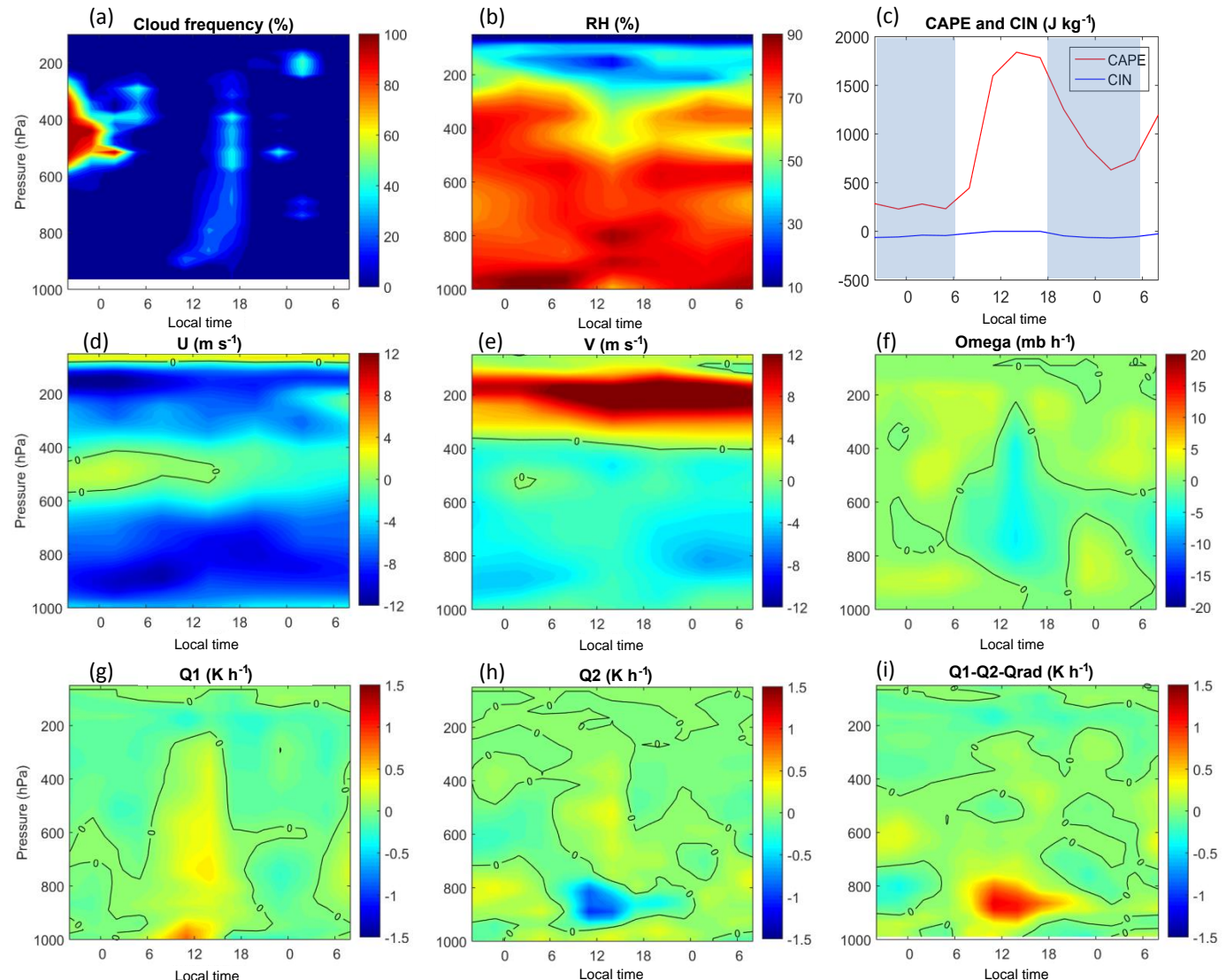

Figure 10. The time series of (a) cloud frequency, (b) relative humidity, (c) surface CAPE and CIN, (d) $u$ wind, (e) $v$ wind, (f) vertical velocity, (g) $Q_{1}$, (h) $Q_{2}$ and (i) $Q_{1}-Q_{2}-Q_{\text {rad }}$ for the LOS case. The black lines are zero-lines. The shaded and white areas in (b) indicate nighttime and daytime.

gating convective systems contributes to the variation of the diurnal cycle between the wet and dry seasons.

The three selected cases are a LOS starting from 11:00 LT, 13 March 2014, a COS starting from 23:00 LT, 20 February 2014, and a BOS starting from 17:00 LT, 1 March 2014. The times of these events are marked by the black lines in Fig. 3. Midlevel wind was dominated by westerlies on 1 March (day 60) and easterlies on 20 February (day 51). Figure 9 shows representative scans of the radar reflectivity at elevation angle of $0.9^{\circ}$ for these three cases, as well as the time series of the domain-mean precipitation. The LOS case has many small- scale scattered convective cells that last for very short times (typically a couple of hours). Because of the small horizontal coverage of the convective cells, the domain-mean precipitation is less than that in the other two cases. The COS case has a clear bow-shaped echo, indicating a squall line front which moves quickly westward. The BOS case has a larger horizontal area of moderate precipitation with some embedded convective cells. It moves southeastward and lasts more than $10 \mathrm{~h}$ over the GoAmazon domain.

The point-observed cloud frequency and domain-averaged relative humidity, surface CAPE and CIN, $u$ and $v$ winds, 


\section{$\cos (20-21$ February 2014)}
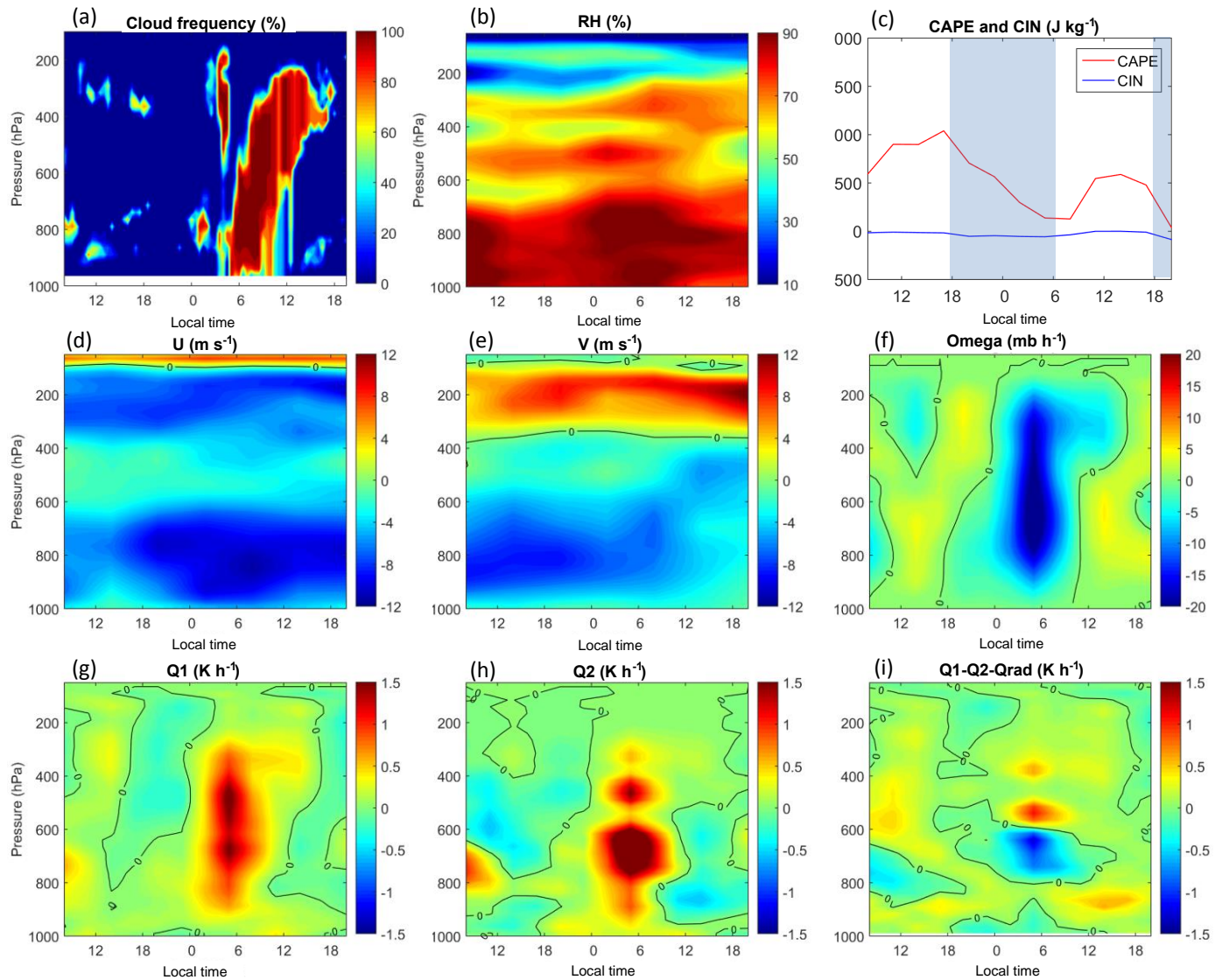

Figure 11. Similar as Fig. 10 but for the COS case.

large-scale vertical velocity, $Q_{1}, Q_{2}$ and $Q_{1}-Q_{2}-Q_{\text {rad }}$ for the three cases are shown in Figs. 10-12, respectively. For the LOS case, the cloud frequency is much smaller than in the other two cases, since the convective cells have small horizontal extent and only occupy a small portion of the region. A shallow-to-deep transition of convective clouds can be seen. The surface CAPE is large, with weak midlevel winds and moist air at the surface before the convection occurred. Upward motion corresponds to the deep convection, and the magnitude is smaller than in the other two cases, consistent with weaker precipitation. Starting around 09:00 LT, $Q_{1}$ shows diabatic heating throughout the troposphere during the deep convection, while $Q_{2}$ shows strong moistening between 750 and $950 \mathrm{hPa}$ and weak drying above that layer. The daytime positive $Q_{1}-Q_{2}-Q_{\text {rad }}$ between 750 and $950 \mathrm{hPa}$ is mainly contributed by negative $Q_{2}$ representing vertical convergence of moisture by sub-grid eddies. It can also be seen on many other days during the two IOPs and are similar to the daytime profiles discussed in the diurnal cycle (Sect. 5). Note that there is a time lag between observed cloud frequency and the domain-averaged large-scale fields, which might be partially due to the fact that the cloud frequency observations were taken from vertically pointing instruments at the ARM site $67.8 \mathrm{~km}$ downwind of the center of the GoAmazon domain.

The COS (Fig. 11) and BOS (Fig. 12) cases both show a shallow-to-deep convective cloud transition from the previous evening to late afternoon, with a moist lower-level atmosphere. Both cases have smaller surface CAPE than the LOS case, possibly because the convective systems have released the atmospheric instability in the morning. The COS case passed through the GoAmazon domain around 06:00 LT in strong midlevel easterlies, with deep clouds and strong upward motion associated with the squall line. Stratiform clouds, associated with weak upward motion, remained in the upper levels until $\sim 18$ :00 LT. Condensation from the deep convection contributes to strong diabatic heating and drying throughout the troposphere, while, after the passage of the squall line (12:00-18:00 LT), there are some stratiform clouds remaining indicated by upper-level heating/drying and lower-level cooling/moistening. The BOS case entered the GoAmazon domain earlier than the COS case. In weak midlevel westerlies and descending mid-tolow-level northerlies, the system moved slowly southeast- 


\section{BOS (1 - 2 March 2014)}
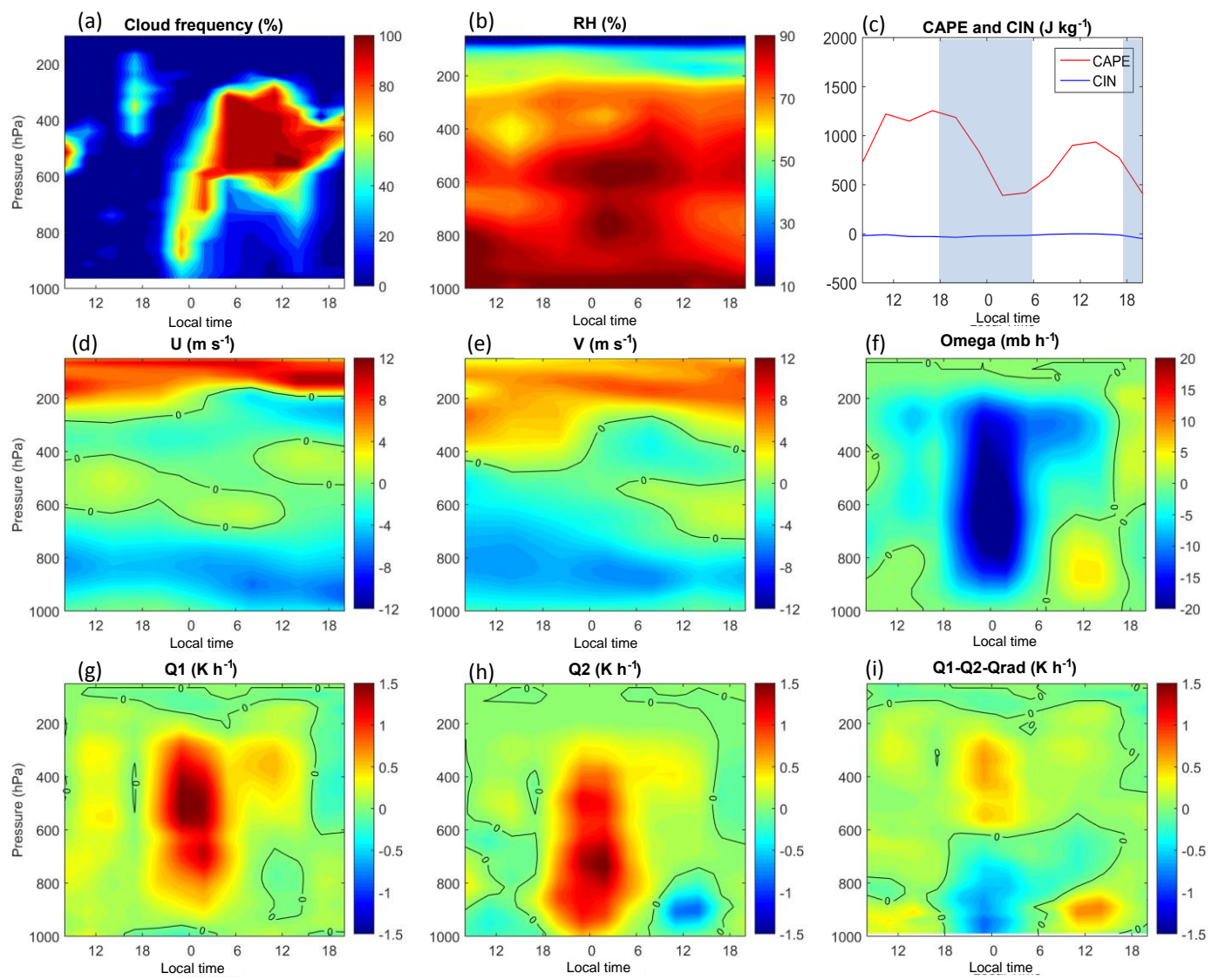

Figure 12. Similar as Fig. 10 but for the BOS case.

ward and remained in the domain for a longer time. Strong upward motion related to the MCS is seen from 18:00 to 06:00 LT. Large diabatic heating and drying related to the strong condensation is also seen. The remnant high clouds were maintained until $\sim$ 18:00 LT with precipitation weakening over time. The upper-level heating and drying, lowerlevel cooling and moistening indicate that there are precipitating stratiform clouds in the upper level and evaporation of precipitation underneath. The negative $Q_{1}-Q_{2}-Q_{\text {rad }}$ in the lower level and the positive $Q_{1}-Q_{2}-Q_{\text {rad }}$ in the upper level are seen in both the COS and BOS case, which indicates lower-level divergence of $h$ and upper-level convergence of $h$ due to moist convective processes, consistent with Tang and Zhang (2015). The lower-level positive $Q_{1}-Q_{2}-Q_{\text {rad }}$ in the afternoon is mainly contributed by the vertical convergence of moisture by sub-grid eddies, similar to that in the LOS case.

\section{Summary and discussion}

This study presented the characteristics of the seasonal variation and diurnal cycle of the large-scale vertical velocity and diabatic heating $\left(Q_{1}\right)$ and drying $\left(Q_{2}\right)$ profiles for the two IOPs conducted during the GoAmazon2014/5 experiment. A constrained variational analysis method was used to derive the large-scale vertical velocity and $Q_{1}$ and $Q_{2}$ profiles based on surface and TOA observations and ECMWF analysis. The derived profiles correspond well with observed clouds and precipitation describing convective systems over Amazonia.

The large-scale environment over the region near Manaus has distinct seasonal variations and diurnal cycles. The wet season (IOP1) has more frequent precipitation events than the dry season (IOP2), especially in the morning. The large-scale upward motions during rainy periods have similar strength in both IOPs, but the peak level in IOP1 is much higher than that exhibited in IOP2 ( $350 \mathrm{hPa}$ vs. $550 \mathrm{hPa}) . Q_{1}$ and $Q_{2}$ both have a double-peak feature during rainy period, but the physical mechanism may be different: the double peak of $Q_{1}$ may be due to the combination of shallow and deep convections and latent cooling near the melting level, while the double peak of $Q_{2}$ may be due to the different height of convective and stratiform systems. The seasonal contrast is mainly due to the higher occurrence of morning mesoscale convective systems observed during IOP1. In the 
morning, upward motion peaks at $\sim 700 \mathrm{hPa}$ and extends to the upper troposphere during IOP1, while it is limited to the lower levels with downward motion at the upper levels during IOP2. Afternoon convective systems have a higher vertical motion peak than their morning counterparts, and both IOPs show similar vertical structures for the afternoon systems. The large-scale vertical velocity shows upward motion above $700 \mathrm{hPa}$ and downward motion below. Accordingly, $Q_{1}$ and $Q_{2}$ also exhibit middle- and upper-level heating and drying related to the deep convection. Below $750 \mathrm{hPa}$, the profiles show relatively weak heating and strong moistening. This heating and moistening feature is due to the vertical convergence of heat and moisture by sub-grid eddies in the boundary layer.

Three cases from IOP1 representing different types of convective systems that often occur in the region were chosen and analyzed in this study: LOS, COS and BOS. The LOS case was characterized by many scattered and short-lived convective cells. It had relatively weak upward motion, heating and drying in the free troposphere and heating and moistening in the boundary layer. The COS case occurred in strong midlevel easterlies. It was characterized as a squall line with deep strong profiles of upward motion, heating and drying. The BOS case mainly happened in weak midlevel westerlies and descending mid-to-low-level northerlies. It was characterized as widespread, moderate precipitation with embedded convective cells and lasted much longer than the other two systems. The precipitating stratiform clouds remained at upper levels for several hours evident by upper-level condensational heating and lower-level evaporative cooling. The frequency of LOS cases is similar in both IOPs while the COS and BOS events occur much more often during the wet season than the dry season. The seasonal variation of the diurnal cycle of precipitation, clouds and environmental variables is mainly due to the COS and BOS events observed in the morning.

Previous studies have also shown that the river breeze has an important influence on the diurnal cycle near the Amazon River (e.g., dos Santos et al., 2014; Tanaka et al., 2014; Burleyson et al., 2016) and that the impact of the local circulation can extend as far as $50 \mathrm{~km}$ away from the river. This local circulation and the horizontal inhomogeneity of largescale vertical velocity, heating and moistening could be better studied using high-resolution 3-D gridded large-scale forcing data from the 3-D constrained variational analysis recently developed by Tang and Zhang (2015) and Tang et al. (2016). This will be the subject of a future study.

\section{Data availability}

The large-scale fields analyzed in this study are released as large-scale forcing data (ARM Climate Research Facility, 2001), which are available at the ARM Archive: (http://iop.archive.arm.gov/arm-iop/
Oeval-data/xie/scm-forcing/iop_at_mao/; see ARM, 2001). The ERA-Interim reanalysis data used to plot Fig. 2 are downloaded from NCAR Research Data Archive (http://rda.ucar.edu/datasets/ds627.0/). The radar loop and the satellite infrared images are available at https://www.youtube.com/playlist? list=PLVqbwaasmlvtcu2kl_U5RaaNF0kYqW6ua and http://www-pm.larc.nasa.gov/cgi-bin/site/showdoc?docid= $22 \&$ domain=satimg_geast_tisa\&lkdomain $=Y$, respectively.

Acknowledgements. The authors gratefully thank Luiz Machado, Jiwen Fan and many others in the GoAmazon group for valuable discussions about the synoptic and climate features in Amazonia region. This research is supported by the Biological and Environmental Research Division in the Office of Sciences of the US Department of Energy (DOE). Work at LLNL was supported by the DOE Atmospheric Radiation Measurement (ARM) program and performed under the auspices of the US Department of Energy by Lawrence Livermore National Laboratory under contract no. DE-AC52-07NA27344. Work at Stony Brook was supported by the Office of Science of the US Department of Energy and by the National Science Foundation. This paper has been authored by employees of Brookhaven Science Associates, LLC, with support from the ARM program and Atmospheric Systems Research Program under contract no. DE-AC02-98CH10886 with the US Department of Energy. Zhe Feng at the Pacific Northwest National Laboratory (PNNL) is supported by the US DOE, as part of the Atmospheric System Research (ASR) Program. PNNL is operated for DOE by Battelle Memorial Institute under contract DE-AC05-76RL01830. Work at ECMWF was supported by the US Department of Energy via the Atmospheric Systems Research Program under contract no. DE-SC0005259. The satellite analyses are supported by the DOE ARM and ASR program under contract, DE-SC0013896. We thank The Brazilian National Institute of Amazonian Research (INPA), the Amazonas State University (UEA) and Antonio Manzi for providing surface flux data.

Edited by: M. Assuncao Silva Dias

Reviewed by: A. K. Betts, E. Souza, and J. Cohen

\section{References}

Ahmed, F., Schumacher, C., Feng, Z., and Hagos, S.: A Retrieval of Tropical Latent Heating Using the 3D Structure of Precipitation Features, J. Appl. Meteorol. Clim., 55, 1965-1982, doi:10.1175/JAMC-D-15-0038.1, 2016.

Atmospheric Radiation Measurement (ARM) Climate Research Facility, updated hourly. Radiative Flux Analysis (RADFLUX1LONG). 2014-02-15 to 2014-10-10, 3.21297 S 60.5981 W: ARM Mobile Facility (MAO) Manacapuru, Amazonas, Brazil; AMF1 (M1), compiled by: Long, C., Gaustad, K., and Riihimaki, L., Atmospheric Radiation Measurement (ARM) Climate Research Facility Data Archive: Oak Ridge, Tennessee, USA, last access: 9 March 2016 at doi:10.5439/1179822, 1994.

Atmospheric Radiation Measurement (ARM) Climate Research Facility, updated monthly. SCM-Forcing DATA from variational 
analysis (VARANAL). 2014-02-18 to 2014-10-10, $3.21297 \mathrm{~S}$ 60.5981 W: ARM Mobile Facility (MAO) Manacapuru, Amazonas, Brazil; AMF1 (M1), compiled by: Tang, S., Xie, S., and Zhang, Y., Atmospheric Radiation Measurement (ARM) Climate Research Facility Data Archive: Oak Ridge, Tennessee, USA, last access: 22 July 2016 at doi:10.5439/1273323, 2001.

Atmospheric Radiation Measurement (ARM) Climate Research Facility, updated hourly. Quality Controlled Eddy Correlation Flux Measurement (30QCECOR). 2014-02-15 to 2014-10-10, 3.21297 S 60.5981 W: ARM Mobile Facility (MAO) Manacapuru, Amazonas, Brazil; AMF1 (M1), compiled by: McCoy, R., Zhang, Y., and Xie, S., Atmospheric Radiation Measurement (ARM) Climate Research Facility Data Archive: Oak Ridge, Tennessee, USA, last access: 22 March 2016 at doi:10.5439/1097546, 2003.

Burleyson, C. D., Feng, Z., Hagos, S. M., Fast, J., Machado, L. A. T., and Martin, S. T.: Spatial Variability of the Background Diurnal Cycle of Deep Convection around the GoAmazon2014/5 Field Campaign Sites, J. Appl. Meteor. Climatol., 55, 15791598, doi:10.1175/JAMC-D-15-0229.1, 2016.

Cifelli, R., Petersen, W. A., Carey, L. D., Rutledge, S. A., and da Silva Dias, M. A. F.: Radar observations of the kinematic, microphysical, and precipitation characteristics of two MCSs in TRMM LBA, J. Geophys. Res.-Atmos., 107, LBA 44-41-LBA 44-16, doi:10.1029/2000JD000264, 2002.

Cressman, G. P.: AN OPERATIONAL OBJECTIVE ANALYSIS SYSTEM, Mon. Weather Rev., 87, 367-374, doi:10.1175/15200493(1959)087<0367:AOOAS>2.0.CO;2, 1959.

Cutrim, E. M. C., Martin, D. W., Butzow, D. G., Silva, I. M., and Yulaeva, E.: Pilot Analysis of Hourly Rainfall in Central and Eastern Amazonia, J. Climate, 13, 1326-1334, doi:10.1175/15200442(2000)013<1326:PAOHRI>2.0.CO;2, 2000.

Dee, D. P., Uppala, S. M., Simmons, A. J., Berrisford, P., Poli, P., Kobayashi, S., Andrae, U., Balmaseda, M. A., Balsamo, G., Bauer, P., Bechtold, P., Beljaars, A. C. M., van de Berg, L., Bidlot, J., Bormann, N., Delsol, C., Dragani, R., Fuentes, M., Geer, A. J., Haimberger, L., Healy, S. B., Hersbach, H., Hólm, E. V., Isaksen, L., Kållberg, P., Köhler, M., Matricardi, M., McNally, A. P., Monge-Sanz, B. M., Morcrette, J. J., Park, B. K., Peubey, C., de Rosnay, P., Tavolato, C., Thépaut, J. N., and Vitart, F.: The ERA-Interim reanalysis: configuration and performance of the data assimilation system, Q. J. Roy. Meteor. Soc., 137, 553-597, doi:10.1002/qj.828, 2011.

dos Santos, M. J., Silva Dias, M. A. F., and Freitas, E. D.: Influence of local circulations on wind, moisture, and precipitation close to Manaus City, Amazon Region, Brazil, J. Geophys. Res.-Atmos., 119, 13233-213249, doi:10.1002/2014JD021969, 2014.

Feng, Z., McFarlane, S. A., Schumacher, C., Ellis, S., Comstock, J., and Bharadwaj, N.: Constructing a Merged Cloud-Precipitation Radar Dataset for Tropical Convective Clouds during the DYNAMO/AMIE Experiment at Addu Atoll, J. Atmos. Oceanic Tech., 31, 1021-1042, doi:10.1175/JTECH-D-13-00132.1, 2014.

Filho, A. J. P., Carbone, R. E., Tuttle, J. D., and Karam, H. A.: Convective Rainfall in Amazonia and Adjacent Tropics, Atmospheric and Climate Sciences, 5, 137-161, doi:10.4236/acs.2015.52011, 2015.

Fu, R., Zhu, B., and Dickinson, R. E.: How Do Atmosphere and Land Surface Influence Seasonal Changes of Convection in the Tropical Amazon?, J. Climate, 12, 1306-1321,
doi:10.1175/1520-0442(1999)012<1306:HDAALS>2.0.CO;2, 1999.

Fu, R., Dickinson, R. E., Chen, M., and Wang, H.: How Do Tropical Sea Surface Temperatures Influence the Seasonal Distribution of Precipitation in the Equatorial Amazon?, J. Climate, 14, 4003-4026, doi:10.1175/15200442(2001)014<4003:HDTSST>2.0.CO;2, 2001.

Giangrande, S., Toto, T., Jensen, M. P., Bartholomew, M., Feng, Z., Protat, A., Williams, C., Schumacher, C., and Machado, L.: Convective Cloud Vertical Velocity and MassFlux Characteristics from Radar Wind Profiler Observations During GoAmazon2014/5, J. Geophys. Res.-Atmos., 121, doi:10.1002/2016JD025303, 2016.

Greco, S., Swap, R., Garstang, M., Ulanski, S., Shipham, M., Harriss, R. C., Talbot, R., Andreae, M. O., and Artaxo, P.: Rainfall and surface kinematic conditions over central Amazonia during ABLE 2B, J. Geophys. Res.-Atmos., 95, 17001-17014, doi:10.1029/JD095iD10p17001, 1990.

Greco, S., Scala, J., Halverson, J., Massie Jr., H. L., Tao, W.-K., and Garstang, M.: Amazon Coastal Squall Lines. Part II: Heat and Moisture Transports, Mon. Weather Rev., 122, 623-635, doi:10.1175/1520-0493(1994)122<0623:ACSLPI>2.0.CO;2, 1994.

Hack, J. J. and Schubert, W. H.: Some dynamical properties of idealized thermally-forced meridional circulations in the tropics, Meteorl. Atmos. Phys., 44, 101-117, doi:10.1007/BF01026813, 1990.

Harriss, R. C., Wofsy, S. C., Garstang, M., Browell, E. V., Molion, L. C. B., McNeal, R. J., Hoell, J. M., Bendura, R. J., Beck, S. M., Navarro, R. L., Riley, J. T., and Snell, R. L.: The Amazon Boundary Layer Experiment (ABLE 2A): dry season 1985, J. Geophys. Res.-Atmos., 93, 1351-1360, doi:10.1029/JD093iD02p01351, 1988.

Harriss, R. C., Garstang, M., Wofsy, S. C., Beck, S. M., Bendura, R. J., Coelho, J. R. B., Drewry, J. W., Hoell, J. M., Matson, P. A., McNeal, R. J., Molion, L. C. B., Navarro, R. L., Rabine, V., and Snell, R. L.: The Amazon Boundary Layer Experiment: Wet season 1987, J. Geophys. Res.-Atmos., 95, 16721-16736, doi:10.1029/JD095iD10p16721, 1990.

Hartmann, D. L., Hendon, H. H., and Houze, R. A.: Some Implications of the Mesoscale Circulations in Tropical Cloud Clusters for Large-Scale Dynamics and Climate, J. Atmos. Sci., 41, 113-121, doi:10.1175/15200469(1984)041<0113:SIOTMC>2.0.CO;2, 1984.

Janowiak, J. E., Kousky, V. E., and Joyce, R. J.: Diurnal cycle of precipitation determined from the CMORPH high spatial and temporal resolution global precipitation analyses, J. Geophys. Res.Atmos., 110, D23105, doi:10.1029/2005JD006156, 2005.

Johnson, R. H.: Partitioning Tropical Heat and Moisture Budgets into Cumulus and Mesoscale Components: Implications for $\mathrm{Cu}-$ mulus Parameterization, Mon. Weather Rev., 112, 1590-1601, doi:10.1175/1520-0493(1984)112<1590:PTHAMB>2.0.CO;2, 1984.

Johnson, R. H. and Lin, X.: Episodic Trade Wind Regimes over the Western Pacific Warm Pool, J. Atmos. Sci., 54, 2020-2034, doi:10.1175/1520-0469(1997)054<2020:ETWROT>2.0.CO;2, 1997. 
Johnson, R. H., Ciesielski, P. E., and Rickenbach, T. M.: A Further Look at Q1 and Q2 from TOGA COARE, Meteor. Mon., 56, 1.11.12, doi:10.1175/AMSMONOGRAPHS-D-15-0002.1, 2016.

Khaiyer, M., Minnis, P., Doelling, D. R., Nordeen, M. L., Palikonda, R., Rutan, D. A., and Yi, Y.: Improved TOA broadband shortwave and longwave fluxes derived from satellites over the Tropical Western Pacific, 13th Conference on Atmospheric Radiation, Am. Meteorol. Soc., Portland, OR, 27 June to 2 July, 2010.

Kollias, P., Miller, M. A., Luke, E. P., Johnson, K. L., Clothiaux, E. E., Moran, K. P., Widener, K. B., and Albrecht, B. A.: The Atmospheric Radiation Measurement Program Cloud Profiling Radars: Second-Generation Sampling Strategies, Processing, and Cloud Data Products, J. Atmos. Ocean. Tech., 24, 1199 1214, doi:10.1175/JTECH2033.1, 2007.

Lau, K. M. and Peng, L.: Origin of Low-Frequency (Intraseasonal) Oscillations in the Tropical Atmosphere. Part I: Basic Theory, J. Atmos. Sci., 44, 950-972, doi:10.1175/15200469(1987)044<0950:OOLFOI>2.0.CO;2, 1987.

Li, W., Fu, R., and Dickinson, R. E.: Rainfall and its seasonality over the Amazon in the 21st century as assessed by the coupled models for the IPCC AR4, J. Geophys. Res.-Atmos., 111, D02111, doi:10.1029/2005JD006355, 2006.

Lin, X. and Johnson, R. H.: Heating, Moistening, and Rainfall over the Western Pacific Warm Pool during TOGA COARE, J. Atmos. Sci., 53, 3367-3383, doi:10.1175/15200469(1996)053<3367:HMAROT>2.0.CO;2, 1996.

Machado, L. A. T., Laurent, H., Dessay, N., and Miranda, I.: Seasonal and diurnal variability of convection over the Amazonia: A comparison of different vegetation types and large scale forcing, Theor. Appl. Climatol., 78, 61-77, doi:10.1007/s00704-0040044-9, 2004.

Machado, L. A. T., Silva Dias, M. A. F., Morales, C., Fisch, G., Vila, D., Albrecht, R., Goodman, S. J., Calheiros, A. J. P., Biscaro, T., Kummerow, C., Cohen, J., Fitzjarrald, D., Nascimento, E. L., Sakamoto, M. S., Cunningham, C., Chaboureau, J.-P., Petersen, W. A., Adams, D. K., Baldini, L., Angelis, C. F., Sapucci, L. F., Salio, P., Barbosa, H. M. J., Landulfo, E., Souza, R. A. F., Blakeslee, R. J., Bailey, J., Freitas, S., Lima, W. F. A., and Tokay, A.: The Chuva Project: How Does Convection Vary across Brazil?, B. Am. Meteorol. Soc., 95, 1365-1380, doi:10.1175/BAMS-D-13-00084.1, 2014.

Marengo, J. A., Liebmann, B., Grimm, A. M., Misra, V., Silva Dias, P. L., Cavalcanti, I. F. A., Carvalho, L. M. V., Berbery, E. H., Ambrizzi, T., Vera, C. S., Saulo, A. C., Nogues-Paegle, J., Zipser, E., Seth, A., and Alves, L. M.: Recent developments on the South American monsoon system, Int. J. Climatol., 32, 1-21, doi:10.1002/joc.2254, 2012.

Martin, S. T., Artaxo, P., Machado, L. A. T., Manzi, A. O., Souza, R. A. F., Schumacher, C., Wang, J., Andreae, M. O., Barbosa, H. M. J., Fan, J., Fisch, G., Goldstein, A. H., Guenther, A., Jimenez, J. L., Pöschl, U., Silva Dias, M. A., Smith, J. N., and Wendisch, M.: Introduction: Observations and Modeling of the Green Ocean Amazon (GoAmazon2014/5), Atmos. Chem. Phys., 16, 47854797, doi:10.5194/acp-16-4785-2016, 2016.

Minnis, P. and Harrison, E. F.: Diurnal Variability of Regional Cloud and Clear-Sky Radiative Parameters Derived from GOES Data. Part II: November 1978 Cloud Distributions, J. Clim. Appl. Meteorol., 23, 1012-1031, doi:10.1175/15200450(1984)023<1012:DVORCA>2.0.CO;2, 1984.
Minnis, P. and Smith, W. L.: Cloud and radiative fields derived from GOES- 8 during SUCCESS and the ARM-UAV spring 1996 flight series, Geophys. Res. Lett., 25, 1113-1116, doi:10.1029/98GL00301, 1998.

Neale, R. B., Chen, C.-C., Gettelman, A., Lauritzen, P. H., Park, S., williamson, D., conley, A., Garcia, R., Kinnison, D., Lamarque, J., Marsh, D., Mills, M., Smith, A., Tilmes, S., Vitt, F., Morrison, H., Cameron-Smith, P., Collins, W. D., Iacono, M., Easter, R., Ghan, S. J., Liu, X., Rasch, P. J., and Taylor, M. A.: Description of the NCAR Community Atmosphere Model (CAM 5.0), NCAR Technical Note NCARTN-4861STR, 274, 2012.

Nitta, T. and Esbensen, S.: Heat and Moisture Budget Analyses Using BOMEX Data, Mon. Weather Rev., 102, 17-28, doi:10.1175/1520-0493(1974)102<0017:HAMBAU>2.0.CO;2, 1974.

Nobre, C. A., Obregón, G. O., Marengo, J. A., Fu, R., and Poveda, G.: Characteristics of Amazonian Climate: Main Features, in: Amazonia and Global Change, American Geophysical Union, 149-162, 2009.

Puri, K.: Some Experiments on the Use of Tropical Diabatic Heating Information for Initial State Specification, Mon. Weather Rev., 115, 1394-1406, doi:10.1175/15200493(1987)115<1394:SEOTUO>2.0.CO;2, 1987.

Schumacher, C. and Houze, R. A.: Stratiform Rain in the Tropics as Seen by the TRMM Precipitation Radar*, J. Climate, 16, 1739-1756, doi:10.1175/15200442(2003)016<1739:SRITTA>2.0.CO;2, 2003.

Schumacher, C., Zhang, M. H., and Ciesielski, P. E.: Heating Structures of the TRMM Field Campaigns, J. Atmos. Sci., 64, 25932610, doi:10.1175/JAS3938.1, 2007.

Schumacher, C., Ciesielski, P. E., and Zhang, M. H.: Tropical Cloud Heating Profiles: Analysis from KWAJEX, Mon. Weather Rev., 136, 4289-4300, doi:10.1175/2008MWR2275.1, 2008.

Silva Dias, M. A. F., Petersen, W., Silva Dias, P. L., Cifelli, R., Betts, A. K., Longo, M., Gomes, A. M., Fisch, G. F., Lima, M. A., Antonio, M. A., and Albrecht, R. I.: A case study of convective organization into precipitating lines in the Southwest Amazon during the WETAMC and TRMM-LBA, J. Geophys. Res.-Atmos., 107, LBA 46-41-LBA 46-23, doi:10.1029/2001JD000375, 2002a.

Silva Dias, M. A. F., Rutledge, S., Kabat, P., Silva Dias, P. L., Nobre, C., Fisch, G., Dolman, A. J., Zipser, E., Garstang, M., Manzi, A. O., Fuentes, J. D., Rocha, H. R., Marengo, J., PlanaFattori, A., Sá, L. D. A., Alvalá, R. C. S., Andreae, M. O., Artaxo, P., Gielow, R., and Gatti, L.: Cloud and rain processes in a biosphere-atmosphere interaction context in the Amazon Region, J. Geophys. Res.-Atmos., 107, LBA 39-31-LBA 39-18, doi:10.1029/2001JD000335, 2002b.

Tanaka, L. M. d. S., Satyamurty, P., and Machado, L. A. T.: Diurnal variation of precipitation in central Amazon Basin, Int. J. Climatol., 34, 3574-3584, doi:10.1002/joc.3929, 2014.

Tang, S. and Zhang, M.: Three-dimensional constrained variational analysis: Approach and application to analysis of atmospheric diabatic heating and derivative fields during an ARM SGP intensive observational period, J. Geophys. Res.-Atmos., 120, 7283 7299, doi:10.1002/2015JD023621, 2015.

Tang, S., Zhang, M., and Xie, S.: An ensemble constrained variational analysis of atmospheric forcing data and its application to evaluate clouds in CAM5, J. Geophys. Res.-Atmos., 121, 33-48, doi:10.1002/2015JD024167, 2016. 
Williams, E., Rosenfeld, D., Madden, N., Gerlach, J., Gears, N., Atkinson, L., Dunnemann, N., Frostrom, G., Antonio, M., Biazon, B., Camargo, R., Franca, H., Gomes, A., Lima, M., Machado, R., Manhaes, S., Nachtigall, L., Piva, H., Quintiliano, W., Machado, L., Artaxo, P., Roberts, G., Renno, N., Blakeslee, R., Bailey, J., Boccippio, D., Betts, A., Wolff, D., Roy, B., Halverson, J., Rickenbach, T., Fuentes, J., and Avelino, E.: Contrasting convective regimes over the Amazon: Implications for cloud electrification, J. Geophys. Res.-Atmos., 107, LBA 50-51LBA 50-19, doi:10.1029/2001JD000380, 2002.

Xie, S., Cederwall, R. T., and Zhang, M.: Developing long-term single-column model/cloud system-resolving model forcing data using numerical weather prediction products constrained by surface and top of the atmosphere observations, J. Geophys. Res., 109, D01104, doi:10.1029/2003jd004045, 2004.

Xie, S., Hume, T., Jakob, C., Klein, S. A., McCoy, R. B., and Zhang, M.: Observed Large-Scale Structures and Diabatic Heating and Drying Profiles during TWP-ICE, J. Climate, 23, 57-79, doi:10.1175/2009jcli3071.1, 2010a.

Xie, S., McCoy, R. B., Klein, S. A., Cederwall, R. T., Wiscombe, W. J., Jensen, M. P., Johnson, K. L., Clothiaux, E. E., Gaustad, K. L., Long, C. N., Mather, J. H., McFarlane, S. A., Shi, Y., Golaz, J.-C., Lin, Y., Hall, S. D., McCord, R. A., Palanisamy, G., and Turner, D. D.: CLOUDS AND MORE: ARM Climate Modeling Best Estimate Data, B. Am. Meteorol. Soc., 91, 1320, doi:10.1175/2009BAMS2891.1, 2010b.
Yanai, M., Esbensen, S., and Chu, J.-H.: Determination of Bulk Properties of Tropical Cloud Clusters from Large-Scale Heat and Moisture Budgets, J. Atmos. Sci., 30, 611-627, doi:10.1175/1520-0469(1973)030<0611:DOBPOT>2.0.CO;2, 1973.

Zhang, M. and Lin, J.: Constrained Variational Analysis of Sounding Data Based on Column-Integrated Budgets of Mass, Heat, Moisture, and Momentum: Approach and Application to ARM Measurements, J. Atmos. Sci., 54, 1503-1524, doi:10.1175/1520-0469(1997)054<1503:CVAOSD>2.0.CO;2, 1997.

Zhang, M., Lin, J., Cederwall, R. T., Yio, J. J., and Xie, S. C.: Objective Analysis of ARM IOP Data: Method and Sensitivity, Mon. Weather Rev., 129, 295-311, doi:10.1175/15200493(2001)129<0295:OAOAID>2.0.CO;2, 2001. 